\begin{tabular}{|l|l|l||}
\hline \multicolumn{2}{|c|}{ PublisherInfo } \\
\hline \hline PublisherName & $:$ & BioMed Central \\
\hline \hline PublisherLocation & $:$ & London \\
\hline \hline PublisherImprintName & $:$ & BioMed Central \\
\hline \hline
\end{tabular}

\title{
Activin can activate p38 MAPK
}

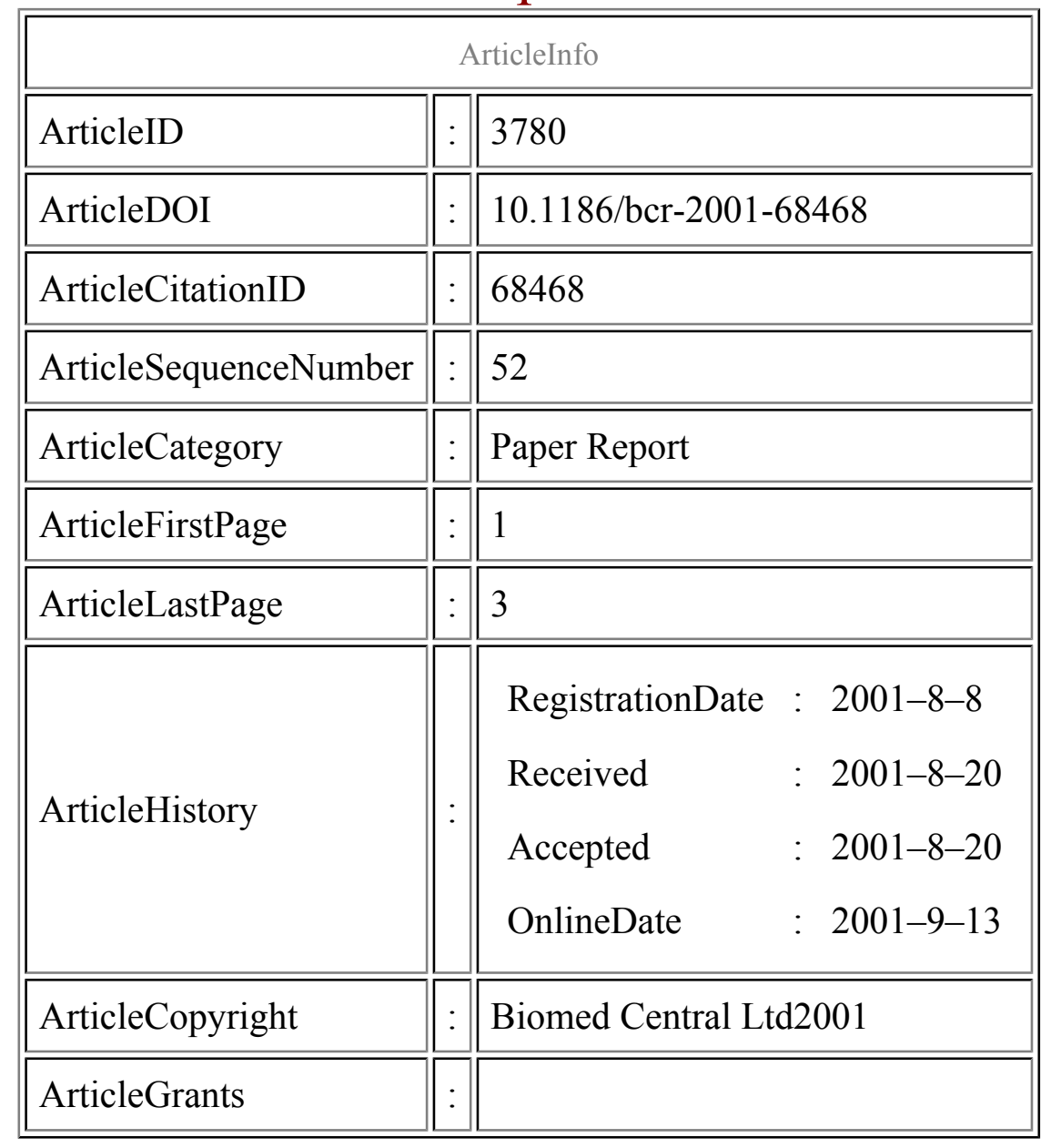




\begin{tabular}{|l|l|l||}
\hline ArticleContext & $:$ & 1305833 \\
\hline
\end{tabular}

Elena Neumann, ${ }^{\text {Aff1 }}$

Affl University Hospital Regensburg, Germany

\section{Keywords}

Activin, cell growth, growth arrest, p38 MAPK, signaling, Smad

\section{Context}

Activin, a member of the transforming growth factor (TGF)? family of growth factors, is known to be a potential growth inhibitor in various tissues and a potential regulator of inflammation by downregulation of proinflammatory cytokines, like interleukin (IL)-1 and IL-6. Activin is overexpressed in several diseases, e.g. in the synovium of rheumatoid arthritis, which is characterized by inflammation and hyperplasia. Intracellular signaling of cellular growth arrest mediated by activin involves Smad proteins, but other molecular pathways still have to be clarified. The aim of this study was to characterize the intracellular signaling of activin that leads to cell growth inhibition.

\section{Significant findings}

The authors analyzed the signaling of activin in a breast cancer cell line (T47D), which showed a strong decrease of cell growth after treatment with activin. By analyzing the activation of several transcription factors and signaling cascades, the authors showed that in addition to the induction of Smads the p38 mitogen-activated protein kinases (MAPK) pathway was activated in T47D cells after activin-induced inhibition of cell growth. The mRNA levels for two cyclin-dependent kinase inhibitors $\left(\mathrm{p} 15^{\mathrm{INK} 4 \mathrm{~B}}\right.$ and $\left.\mathrm{p} 21^{\mathrm{CIP} 1 / \mathrm{WAF} 1}\right)$ increased following stimulation with activin.

\section{Comments}


To date, the signaling of activin-induced inhibition of cell growth is not well understood. This paper provides a novel link between the p38 MAPK pathway and activin-mediated cell growth arrest. In addition, the authors suggest an involvement of $\mathrm{p} 15^{\mathrm{INK} 4 \mathrm{~B}}$ and $\mathrm{p} 21^{\mathrm{CIP} 1 / \mathrm{WAF} 1}$ in cell growth arrest. Unfortunately, protein expression could not be detected, possibly due to low levels of expression. Furthermore, it would be interesting to know which doses of activin lead to an inhibition of cell growth, whether these concentrations are physiological and whether the activation of the MAPK pathway is restricted to cells that are co-stimulated with epidermal growth factor, as reported in the present study, or whether unstimulated cells respond in the same way. The following points should be addressed in future studies: do other cell lines show the same activation pattern as the breast cancer cell line T47D, and is this signaling pathway a general pathway to induce cell growth arrest or is it cell/tissue/disease specific? Finally, does the p38 MAPK pathway require the parallel activation of the Smad pathway?

\section{Methods}

Proliferation assay, transfection by electroporation and reporter assay, RNase protection assay, western blotting

\section{Additional information}

\section{References}

1. Cocolakis E, Lemay S, Ali S, Lebrun JJ: The p38 MAPK pathway is required for cell growth inhibition of human breast cancer cells in response to activin. J Biol Chem. 2001, 276: 18430-18436. 